Голокост (с. 315-318). Його стаття висвітлює також і іншу тему, а саме велику роль Євгенія Євтушенка та його поеми 1961 р. про Бабин Яр у поширенні на весь світ історії про нищення людей у вересні 1941 р. Редліх змальовує, як він вперше дізнався про це завдяки поемі Евтушенка в 1960-х рр.

Мирослав Маринович у своєму завершальному «Post Scriptum» навпаки намагається запропонувати розв'язання проблеми різних тлумачень та різного сприйняття Бабиного Яру, висловленої Нахмановичем (с. 319-324). Він відстоює свою позицію про те, що немає необхідності у прийнятті необачних рішень, а навпаки існує необхідність у веденні широкого відкритого діалогу, що спирається на історичні та наукові дослідження і має стати основою для прийняття рішення про відповідну форму пам’яті.

Загалом збірник є вагомим внеском до поглиблення та поширення знань про Бабин Яр та створення діалогу, якого прагне Мирослав Маринович, про те, яке значення має Бабин Яр у наші часи та як необхідно пам'ятати про це місце. Водночас видання знайомить з деякими відкритими питаннями наукових досліджень, серед яких не лише масштабне нищення 29 та 30 вересня 1941 р., а більшою мірою вбивства, скоєні на цьому місці пізніше. Це стосується також різних аспектів історії пам'яті, серед яких не останнім є поширення знань про Бабин Яр у міжнародній спільноті після 1945 р.

Переклала з німецької Валерія Колесниченко

${ }^{1}$ Тімоті Снайдер, Чорна земля. Голокост як історія і застереження (Київ: Медуза, 2017).

${ }^{2}$ Для прикладу можна назвати міжнародну дискусію за участі Ентоні Полонскі, Дітера Поля та Кая Струве, опубліковану на Форумі часопису «Україна модерна», див.: Antony Polonsky, Дітер Поль і Кай Струве, «Дискусія навколо книжки Тімоті Снайдера Black Earth: The Holocaust as History and Warning (New York: Tim Duggan Books, 2015)», Україна модерна 24: Єврейські історії українських теренів (2017): 202-233.

\section{СЛАВІК Ю. ШЛЯХ ДО АУШВІЦУ: ГОЛОКОСТ НА ЗАКАРПАТТІ. ДНІПРО: УКРАЇНСЬКИЙ ІНСТИТУТ ВИВЧЕННЯ ГОЛОКОСТУ “ТКУМА», 2017.156 С.}

Історія Голокосту впродовж останніх десятиліть належить до провідних тем сучасної світової історіографії. Відповідно існує величезна кількість досліджень найрізноманітнішого характеру: від «подієвого» наративу до концептуально-засадничих праць, автори яких намагаються осмислити причини та проблеми страшної трагедії XX століття в глобальній перспективі, запропонувати нові методологічні підходи, концепції та теорії. До прикладу, книжка Тімоті Снайдера «Чорна земля. Голокост як історія і застереження»'. Праці такого гатунку зазвичай породжують гострі дискусії', які слугують кращому розумінню історії винищення євреїв в роки Другої світової війни і дають поштовх до нових досліджень.

На жаль, не можна ще сказати про такі ж успіхи української історіографії, де дослідження Голокосту розпочались на добрих два десятиліття пізніше ніж на Заході. До того ж на них позначилось і небезболісне вивільнення пострадянської історичної науки від марксистсько-ленінської методології й дещо спорадичне оволодіння новим методологічним інструментарієм, слабке знання іноземних мов істориками старших поколінь, незабезпеченість бібліотек працями західних авторів, насамперед концептуального характеру та першочерговість інтересу і запиту на творення національного етноцентричного наративу задля легітимації державності. Правда, як засвідчує проведений історіографічний аналіз у недавніх публікаціях 
Анни Медведовської,'Ігоря Щупака та Олексія Гончаренка', певні здобутки і поступ української історіографії є очевидними.

Однак, якщо в академічній царині можна констатувати певні успіхи, то в суспільному пам'яттєвому дискурсі тема Голокосту належить до другорядних і найперше асоціюється з трагедією Бабиного Яру. Хоча на території України є чимало місць, де відбувались жорстокі знищення тисяч євреїв упродовж декількох днів, наприклад 23-25 жовтня 1941 р. в Одесі'. Та пам'ять про цю трагедію доволі повільно утверджується не тільки на державному рівні, а й у місцевому публічному дискурсі. Ще більш маргіналізованою є пам'ять про трагедію євреїв Закарпаття, що певною мірою обумовлено стереотипом про відносно «цивілізований антисемітизм» угорської влади. Означені проблеми актуалізують вивчення регіональних особливостей трагедії єврейства і широку репрезентацію цих досліджень. Очевидно, що це добре розуміють і намагаються вирішити в Українському інституті вивчення Голокосту «Ткума». Останніми роками в серії «Українська бібліотека Голокосту» видано декілька праць про трагічну історію євреїв окремих регіонів та різних окупаційних зон України. Серед них і книжка молодого ужгородського дослідника Юрія Славіка про Голокост на Закарпатті.

Монографія розпочинається з короткої згадки історії заселення краю євреями та їх життя в Чехословацькій республіці, як золотих років перед катастрофою. Це є вельми важливим, оскільки вкотре засвідчує, що демократичні засади і виважена національна політика $\epsilon$ підгрунтям мирного співжиття представників різних етносів та народів (с. 6). Вірогідно така політика стала й запорукою того, що навіть у розпал антисемітизму на Закарпатті, як показує дослідження Ю. Славіка, не зафіксовано випадків єврейських погромів. Хоча в роботі автор не акцентує увагу на такому взаємозв'язку. Наведені статистичні дані переконливо доводять репрезентативність єврейства в Закарпатті (в окремих містах їх частка перевищувала 40\%) та його

${ }^{3}$ Анна Медведовська, «До питання про сучасну українську історіографію Голокосту», Сторінки історії 35 (2013): 189-196, http://nbuv.gov.ua/UJRN/Sisi_2013_35_19.

${ }^{4}$ Ігор Щупак, «Уроки Голокосту в українській історичній науці та освіті: від наративу до осмислення й постановки суспільного питання про покаяння (до 75-ї річниці трагедії Бабиного Яру)», Український історичний журнал, № 4 (2016): 152-172, http://resource.history.org.ua/publ/UIJ_2016_4_12.

5 Олексій Гончаренко, Голокост на теренах Райхскомісаріату «україна» у вітчизняному історіографічному дискурсі (1941-2016 рр.) (Дніпро - Переяслав-Хмельницький: Український інститут вивчення Голокосту «Ткума», 2017).

${ }^{6}$ Александр Круглов, Истребление евреев Одессы в 1941-1943 гг. (Днепропетровск: Институт «Ткума», 2014). вагому роль в економічному, культурному і політичному житті краю житті до часу встановлення угорського правління. Однак для кращої контекстуалізації, й з огляду на те, що в монографії розглянуто відносини між «євреями та неєвреями», бракує статистики щодо представників інших етносів Закарпаття, хоча б численних.

Викладу основного тексту передує історіографічний та джерелознавчий огляд. Дуже добре, що автор бере до уваги й розробку теми в зарубіжній історіографії. Проте, зважаючи на невеликий вітчизняний історіографічний доробок про Голокост на Закарпатті, на що справедливо вказав Ю. Славік, і незначний доступ до іноземних публікацій українських читачів, був би доречним більш грунтовний аналіз зарубіжної історіографії. Наприклад, вказано, що праця американського дослідника Рендольфа Брехема «Політика геноциду: Голокост в Угорщині» стала «основоположною для багатьох дослідників» (с. 12), але не подано ні їі аналіз, ні представлено іï основні концепції.

Дещо подібна картина й з аналізом праць ізраїльських істориків. Відзначивши їх вагомий внесок у дослідження питань життя євреїв Угорського королівства та їх взаємин 3 представниками інших національностей в умовах дії антиєврейських законів, автор зосередився на критиці тези Й.А. Єлінека про антисемітський характер політики уряду Августина Волошина. На значно більшу увагу заслуговують й дослідження угорських фахівців, попри те, що вони, на думку німецької дослідниці Регіни Фрітц (Regina Fritz), переважно описують події, які відбувались під час Голокосту, незначною мірою інтегрують їх у європейський контекст та мало приділяють уваги аналізу і пошуку відповіді на запитання: хто ж тут мав би нести відповідальність?

Основний текст монографії представлено у двох розділах. У першому розглянуто впровадження антиєврейського законодавства після приєднання Закарпаття до Угорщини та життя євреїв краю в умовах антисемітського тиску, проведення їх часткової депортації у 1941 р., мобілізацію та виснажливу працю чоловіків єврейського походження у трудових загонах. Другий розділ - це власне історія жорстокого винищення євреїв та переслідувань ромського населення після вступу військ нацистської Німеччини на територію Угорського королівства i, відповідно, Закарпаття.

${ }^{7}$ Thyra Veyder-Malberg, «Ungarn und der Holocaust», Heute im Osten, November 9, 2017, дата звернення 17 лютого, 2019, https://www.mdr.de/heute-im-osten/holocaust-ungarn-102.html. 
Реконструювавши процес творення обмежувального законодавства щодо євреїв угорською владою на чолі з М. Горті, автор цілком справедливо відзначив його схожість 3 антиєврейськими законами Третього райху, насамперед, з расовими Нюрнберзькими законами 1935 р. (с. 22). Водночас трактування Ю. Славіком причин впровадження обмежень для єврейства в Угорському королівстві породжує низку запитань. Навівши думку угорського дослідника Т. Шторка про те, що, поряд з німецьким впливом, вагомим чинником було й прагнення угорських еліт і середнього класу обмежити вплив єврейства, та американського історика Р. Брехема про антисемітизм угорських робітників і селян, ужгородський дослідник стверджує, що «саме геополітичний вплив Німеччини фактично призвів до ухвалення перших антисемітських законів» (с. 23). Проте чи антисемітизм кінця 30-х рр. був породжений, насамперед, впливом Німеччини та іiі патронатом територіальних «надбань» Угорського королівства і економічними інтересами угорців, чи він мав дещо глибше коріння й обумовлений національною політикою М. Горті в попередні роки? Можливо, відносини з Німеччиною були радше приводом, а не причиною впровадження антисемітського законодавства?

Описуючи різні практики виживання євреїв в умовах дії антисемітських законів та спроби економічного спротиву, Ю. Славік неодноразово вказує на недотримання законодавства i «відносно безпечне» життя євреїв Закарпаття в період угорського правління, який передував окупації німецькими військами. Водночас емпіричний матеріал свідчить про методи прихованого/непрямого їх винищення. Наприклад, представники єврейської громади Мукачева в 1942 р. були позбавлені права на хлібні картки (с. 28), до того ж в умовах планомірного витіснення їх з економічного життя краю, тобто позбавлення заробітку. Було б добре, якби автор більш детально проаналізував наслідки цієї акції, а не просто констатував iii. Антисемітизм і жорстокість угорської влади підтверджує і добре описана автором депортація в 1941 р. євреїв-біженців без громадянства (с. 43-52), у здійсненні якої він, насамперед, звинувачує військових (с. 44-45). Правда, Ю. Славік цілком раціонально пояснює «рішучу протидію угорського керівництва німецьким домаганням» у «єврейському питанні» та політику «еволюційного витіснення євреїв $з$ економічного й суспільного життя в Угорщині», не відсутністю антисемітських переконань у М. Горті та його оточення, а економічною доцільністю і тим, що з часом, особливо після провалу планів блискавичної війни, «єврейське питання» можна було використати в налагодженні контактів з країнами антигітлерівської коаліції (с. 31).

Другий розділ розпочинається з констатації факту вступу 19 березня 1944 р. на території Угорського королівства 11 німецьких дивізій та створення нового маріонеткового уряду, на яких і покладається основна відповідальність за радикалізацію антисемітської та антиромської політики. Водночас нічого не сказано про зміни і склад місцевої влади та поліції Закарпаття, а саме вони «вельми оперативно» переймались не тільки створенням гетто, розміщенням та утриманням у них євреїв, а й організацією їх депортації до таборів смерті навесні й початку літа 1944 р. Наприклад, у Мукачеві деталі «майбутньої депортації були прийняті на серії засідань місцевої влади», на яких головував підполковник жандармерії Ласло Ференці (c. 78). Очевидно підгрунтям цієї оперативності та виконавської дисципліни була й активна антисемітська політика режиму М. Горті в попередні роки і який залишався при владі аж до жовтня 1944 р. Автор чомусь у другому розділі згадує про угорського регента, тільки з огляду на те, що завдяки його втручанню в червні 1944 р., коли вже більшість євреїв відправили на вірну загибель до Аушвіцу, було припинено їх депортації, що врятувало життя фактично тільки євреям столиці (с. 83). Цей факт засвідчує, що навіть за умови перебування німецьких військ М. Горті міг впливати на процес депортації. Однак у книзі відсутні будь-які критичні роздуми з цього приводу при пошуку відповіді на запитання: чи могли закарпатські євреї врятуватися від депортації? Натомість на підставі усних свідчень та досліджень ізраїльських науковців вказано, насамперед, на необізнаність євреїв щодо можливих наслідків переселення їх до гетто і відзначено негативну роль єврейських рад, які «відвертали увагу місцевих євреїв від реальних мотивів» цього заходу (с. 84-86). Як наслідок, у жахливих умовах антисемітської політики та Голокосту на Закарпатті вижити вдалося всього близько $12 \%$ євреїв, хоча, як засвідчує текст монографії, питання встановлення кількості жертв потребує подальшого більш детального вивчення (с. 81-82).

Не залишилась поза увагою Ю. Славіка й доля ромів Закарпаття, які попри утиски (створення гетто, мобілізація до трудових загонів) не зазнали масового винищення. Пояснення цьому автор вбачає в їх маргінальному становищі.

В історії Голокосту тема відносин євреїв і їх сусідів належить до найбільш дискусійних, проблемних і болісних. У рецензованій праці відносини між євреями та представниками інших етносів 
регіону розглянуто в загальноукраїнському контексті. Ю. Славік відзначає, що, на відміну від Галичини та Наддніпрянської України, антисемітська політика в Закарпатті базувалась на економічній, а не антибільшовицькій складовій (с. 88). Її провідниками були не тільки владні структури, а й релігійні організації, наприклад, молодіжна організація при Мукачівській греко-католицькій єпархії (с. 89) та місцева преса, де переважна більшість редакторів мала слов'янське, а не угорське походження (с. 91). Та попри все це не привело до масових єврейських погромів. Водночас, незважаючи на відсутність вельми жорстких покарань за допомогу євреям, переважна більшість населення зайняла позицію «байстендерс», хоча було й чимало тих, зокрема й поміж угорських політиків, хто намагався допомогти євреям, особливо під час їх переселення в гетто (с. 94-96).

Певною мірою книга «Шлях до Аушвіцу: Голокост на Закарпатті» має й джерелознавчий характер, оскільки в ній подано низку документів, але тільки декілька з них є неопублікованими архівними матеріалами та текстами з тогочасної преси. Решта - це передруки з різних збірок документів, зокрема й зі збірки документів «Шляхом Жовтня», виданої в радянські часи. Варто відзначити, що автор опрацював найрізноманітніші види джерел: архівні матеріали (переважно Державного архіву Закарпатської області), опубліковані документи, зокрема, й угорські, тогочасну регіональну пресу та усноісторичні свідчення очевидців Голокосту, які представлені на низці електронних ресурсів. Саме завдяки останнім двом групам джерел перед читачем постає доволі персоніфікована історія, якій дещо бракує авторських рефлексій та аналітико-оціночних суджень.

Праця Ю. Славіка є ще одним кроком в узагальненні історії Голокосту на Закарпатті й вивченні регіональних особливостей цієї трагедії на теренах України та засвідчує необхідність як подальшого дослідження низки питань, порушених у монографії, так і концептуального осмислення цієї теми на загальноукраїнському рівні з більш широкою європейською контекстуалізацією.

\section{ПОШУК ВІДПОВІДІ НА ЗАПИТАННЯ ЧОМУ Я СТАВ НАЦИСТОМ?»: МАЛОВІДОМІ МАТЕРІАЛИ СОЦІОЛОГІЧНОГО ОПИТУВАННЯ 1934 Р. НА TEPЕНАХ ТРЕТЬОГО РАЙХУ.}

Огляд збірки: «Warum ich Nazi wurde» - Biogramme früher Nationalsozialisten. Die einzigarten Sammlung des Theodor Abel / Wieland Giebel. B. Berlin Story Verlag, 2018. 930 s. (“Чому я став нацистом» Біографії ранніх націонал-соціалістів з приватного зібрання Теодора Абеля / Віланд Ґібель. Берлін, Berlin Story Verlag, 2018. 930 c.)

Історичний розвиток, як і будь-які політичні процеси в суспільстві, має різні складові свого поступу. Зараз, на початку нового тисячоліття, першочерговим завданням істориків є комплексний системний аналіз визначних подій і зрушень, надбань і втрат, які були характерними для бурхливого минулого століття. Озираючись назад у ХХ ст., усвідомлюючи грандіозний злет людського розуму, величні досягнення в галузі науки та техніки, визначні здобутки в соціальноекономічній сфері, ми мусимо визнати при цьому, що ані досягнення культури та цивілізації, ані швидкий та потужний індустріальний розвиток провідних країн світу не змогли захистити людство від виникнення в його надрах низки страхітливих тоталітарних режимів. Останні намагались відійти від магістрального шляху розвитку людської цивілізації, поставити під сумнів прогресивні світові завоювання і тотально втрутитися в долю держави, громадянського суспільства тощо. Інтерес до проблеми вивчення генези німецького варіанту фашизму виник серед науковців світу одразу після зародження цього явища.

Тема Третього райху i зараз, знову і знову, привертає увагу дослідників з усього світу не в останню чергу через персоніфікацію учасників політичного процесу минулих років (йдеться про генезу НСДАП), зокрема й пересічних громадян Німеччини. На сьогодні історіографія фашизму вже представлена великою палітрою 